\title{
First-order estimate of the planktic foraminifer biomass in the modern ocean
}

\author{
R. Schiebel and A. Movellan \\ LUNAM Université, Université d'Angers, UMR6112, CNRS LPGN-BIAF, Laboratoire des Bio-Indicateurs \\ Actuels et Fossiles, 2 Boulevard Lavoisier, 49045 Angers CEDEX 01, France
}

Correspondence to: R. Schiebel (ralf.schiebel@univ-angers.fr)

Received: 20 March 2012 - Published in Earth Syst. Sci. Data Discuss.: 27 April 2012

Revised: 10 July 2012 - Accepted: 14 August 2012 - Published: 3 September 2012

\begin{abstract}
Planktic foraminifera are heterotrophic mesozooplankton of global marine abundance. The position of planktic foraminifers in the marine food web is different compared to other protozoans and ranges above the base of heterotrophic consumers. Being secondary producers with an omnivorous diet, which ranges from algae to small metazoans, planktic foraminifers are not limited to a single food source, and are assumed to occur at a balanced abundance displaying the overall marine biological productivity at a regional scale. With a new non-destructive protocol developed from the bicinchoninic acid (BCA) method and nano-photospectrometry, we have analysed the protein-biomass, along with test size and weight, of 754 individual planktic foraminifers from 21 different species and morphotypes. From additional CHN analysis, it can be assumed that proteinbiomass equals carbon-biomass. Accordingly, the average individual planktic foraminifer protein- and carbonbiomass amounts to $0.845 \mu \mathrm{g}$. Samples include symbiont bearing and symbiont-barren species from the sea surface down to $2500 \mathrm{~m}$ water depth. Conversion factors between individual biomass and assemblage-biomass are calculated for test sizes between 72 and $845 \mu \mathrm{m}$ (minimum test diameter). Assemblage-biomass data presented here include 1128 sites and water depth intervals. The regional coverage of data includes the North Atlantic, Arabian Sea, Red Sea, and Caribbean as well as literature data from the eastern and western North Pacific, and covers a wide range of oligotrophic to eutrophic waters over six orders of magnitude of plankticforaminifer assemblage-biomass (PFAB). A first order estimate of the average global planktic foraminifer biomass production $\left(>125 \mu \mathrm{m}\right.$ ) ranges from $8.2-32.7 \mathrm{TgC}^{-1}$ (i.e. $0.008-0.033 \mathrm{GtC} \mathrm{yr}^{-1}$ ), and might be

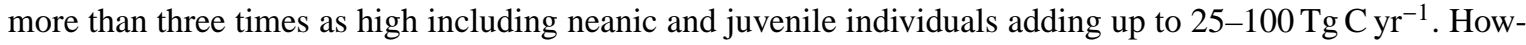
ever, this is a first estimate of regional PFAB extrapolated to the global scale, and future estimates based on larger data sets might considerably deviate from the one presented here. This paper is supported by, and a contribution to the Marine Ecosystem Data project (MAREDAT). Data are available from http://www.pangaea.de (http://doi.pangaea.de/10.1594/PANGAEA.777386).
\end{abstract}

\section{Introduction}

Planktic foraminifers are marine protozoans with calcareous shells and chambered tests. Most of the $\sim 50$ modern (morpho-) species live in surface waters down to the deep chlorophyll maximum of the ocean, and in marginal seas like the Caribbean and Red Sea (Bijma and Hemleben, 1994; Schmuker and Schiebel, 2002). Planktic foraminifers are largely absent from shallow marginal seas like the North Sea (Hemleben et al., 1989). Most of the modern morpho-species are ubiquitious. The highest diversity is recorded from temperate to subtropical waters. Due to meso-scale and local hydrographic features, the distribution of planktic foraminifers is patchy on various temporal and spatial scales (e.g. Siccha et al., 2012). Margins of subtropical gyres and hydrographic fronts are characterized by allochthonous species expatriated by currents (Weyl, 1978).

Planktic foraminifers are affected by the availability of food, and the range of temperature and salinity as well as 
chemistry of the ambient seawater (e.g. Bé, 1977; Hemleben et al., 1989; Bijma et al., 1990; Ortiz et al., 1995; Schiebel et al., 2001; Lombard et al., 2011). Species abundance varies with season, water mass, and water depth (e.g. Schiebel et al., 2001). The vertical separation of species is more evident in the tropics than in polar regions, owing to a wider diversity of hydrographic and biotic variables from surface to depth at low latitudes compared to the more uniform water column at high latitudes (Schiebel and Hemleben, 2005, and references therein). The seasonal distribution pattern of planktic foraminifers is most pronounced in high and mid-latitudes, following phytoplankton succession and availability of food. In polar oceans, a single maximum of planktic foraminiferal production occurs during summer, when euphotic conditions allow for enhanced primary production (Spindler and Dieckmann, 1986; Volkmann, 2000). In mid-latitudes, two seasons of enhanced production occur during spring and fall (Schiebel and Hemleben, 2005). At low latitudes, seasonality is low, and productivity follows regional conditions, such as monsoonal activity and upwelling intensity (Hemleben et al., 1989).

At a global scale, the abundance of planktic foraminifers follows the overall pattern of primary productivity (Schiebel, 2002). In turn, non-lagged correlations of primary productivity and planktic foraminiferal abundance are weak at a regional scale (Schiebel, 2002), possibly because of the omnivorous diet of planktic foraminifers in the marine food web, and phase shifts in the production of phytoplankton and zooplankton (Hemleben et al., 1989). Non-spinose species are largely herbivorous, and spinose species accept a wide variety of animal prey, including larger metazoans, such as copepods, pteropods, and ostracods (Anderson et al., 1979; Caron and Bé, 1984; Spindler et al., 1984). Intermediate-dwelling species are believed to feed on settling organic matter (Itou et al., 2001). Predators specialised on planktic foraminifers have not yet been identified.

Shallow-dwelling species are shown to reproduce once or twice (one species only) per month. Intermediate to deep-dwelling species reproduce less often (Hemleben et al., 1989). Not all specimens reach the reproductive ontogenetic stage during one reproductive cycle and may reproduce later. Growth and abundance of juveniles depends on ecological conditions. Fast growth and high survival rates occur if diet is abundant. The prolocular ontogenetic stage consists of a first chamber built of calcite and ranges from 12-25 $\mu \mathrm{m}$ in diameter (Brummer and Kroon, 1988). The first juvenile chambers are formed on a sub-daily rate, and during ontogeny the speed of chamber formation gradually decreases. The neanic stage is marked by a change in depth habitat, and occasional changes in the selection of diet (Brummer and Kroon, 1988). Adult specimens consist of 10-20 chambers, and tests are between 100 and $1000 \mu \mathrm{m}$ in size (on average $\sim 250 \mu \mathrm{m})$.
The intra-shell cytoplasm of planktic foraminifers is differentiated from reticulate and rhizopodial cytoplasm outside of the test (Hemleben et al., 1989). Cytoplasm reaches far into the ambient seawater along spines, and occasionally forms a rhizopodial net. Food in form the of lipids and starch is stored in special vacuoles (Schiebel and Hemleben, 2005). Symbiont-bearing species depend on light and are bound to the euphotic layer, and subsurface to deep-dwelling species are symbiont-barren (e.g. Bé, 1982).

Although planktic foraminifers constitute only a minor portion of the total zooplankton, they are major producers of marine calcareous shells (called tests). Consequently, planktic foraminifers have been a major target of research in geology and paleoceanography since the 1960s (e.g. Bé, 1977; Vincent and Berger, 1981; Hemleben et al., 1989; and references therein). Planktic foraminifer carbon-biomass was first analysed for three species and 112 individuals from surface water pump samples off Bermuda in 1991 and 1992 (Michaels et al., 1995). The species analysed by Michaels et al. (1995) are also present in our data set, and our new protein-biomass data are discussed to equal carbonbiomass. Conversion factors between carbon-biomass and

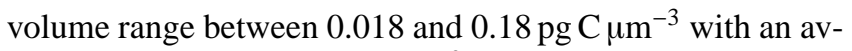

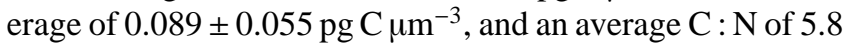
(Michaels et al., 1995).

The objective of this paper is the construction of a database on live planktic foraminifer abundance and biomass, which includes a wide range of water depths and modern productivity regimes between the tropical and polar oceans, and finally an estimate of the planktic foraminifer biomass. The conversion from abundance to assemblage-biomass is based on a first data set on the species- and size-specific protein-biomass. Extrapolating from the resulting regional and seasonal biomass data, a first-order global estimate of the modern planktic-foraminifer assemblage-biomass (PFAB; $\left.\mu \mathrm{g} \mathrm{C}^{-3}\right)$ and biomass production $\left(\mathrm{Tg} \mathrm{C} \mathrm{yr}^{-1}\right)$ is given.

\section{Material and methods}

Planktic-foraminifer assemblage-biomass (PFAB) was calculated for 6100 size fractions from 1057 plankton net samples from the North Atlantic Ocean, Caribbean, Arabian Sea and Gulf of Aden, and Red Sea (Table 1), comprising faunal data from the equatorial to polar oceans (Fig. 1), obtained between 1989 and 1999 (Fig. 2). A large part of the samples were obtained as part of the German contribution to the Joint Global Ocean Flux Studies in the 1990s at stations and transects in the North Atlantic (BIOTRANS) and Arabian Sea repeatedly sampled at seasonal and regional resolution, over a wide range of global marine primary productivity from oligotrophic to eutrophic conditions. In addition, 71 datapoints on live planktic foraminifer assemblages $(>125 \mu \mathrm{m})$ are included from Ortiz et al. (1995) and Kuroyanagi and 
Table 1. Summary of 1128 data points on population dynamics of live planktic foraminifers (> $125 \mu \mathrm{m}) \mathrm{m}^{-3}$, used for the calculation of assemblage biomass. Each data point consists of five test size fractions of planktic foraminifers classified at the species level. All data are available from www.pangaea.de (Schiebel, 2002). Samples around $47^{\circ} \mathrm{N} / 20^{\circ} \mathrm{W}$ (BIOTRANS Station) in the North Atlantic, and in the Arabian Sea were obtained within the JGOFS Program.

\begin{tabular}{|c|c|c|c|c|c|c|c|}
\hline Cruise/Ref. & Year & Month & Location & $\begin{array}{l}\text { Lat. } \\
\left({ }^{\circ} \mathrm{N}\right)\end{array}$ & $\begin{array}{l}\text { Long. } \\
\left({ }^{\circ} \mathrm{W} /{ }^{\circ} \mathrm{E}\right)\end{array}$ & $\begin{array}{l}\text { Water Depth } \\
\text { (m) }\end{array}$ & $\begin{array}{l}\text { No. of } \\
\text { Samples }\end{array}$ \\
\hline R/V Meteor 10/1 & 1989 & April & N Atlantic & 18.5 & $30.5^{\circ} \mathrm{W}$ & $100-500$ & 3 \\
\hline $\mathrm{R} / \mathrm{V}$ Meteor $12 / 3$ & 1990 & June & N Atlantic & $47-47.5$ & $19.5-20^{\circ} \mathrm{W}$ & $0-500$ & 26 \\
\hline R/V Meteor 21/1 & 1992 & March-April & N Atlantic & 47 & $19.5^{\circ} \mathrm{W}$ & $0-2500$ & 62 \\
\hline $\mathrm{R} / \mathrm{V}$ Meteor 21/2 & 1992 & April-May & N Atlantic & 47 & $19.5^{\circ} \mathrm{W}$ & $0-2500$ & 89 \\
\hline $\mathrm{R} / \mathrm{V}$ Meteor $21 / 3$ & 1992 & May & N Atlantic & $47-47.5$ & $19.5-20^{\circ} \mathrm{W}$ & $0-2500$ & 18 \\
\hline R/V Meteor 21/3 & 1992 & May & N Atlantic & 57.5 & $20^{\circ} \mathrm{W}$ & $0-700$ & 9 \\
\hline R/V Meteor 21/5 & 1992 & July & N Atlantic & $67-72.5$ & $8.5^{\circ} \mathrm{W}-3^{\circ} \mathrm{E}$ & $0-2500$ & 62 \\
\hline R/V Poseidon 200/6 & 1993 & June & N Atlantic & 44.8 & $19.8^{\circ} \mathrm{W}$ & $0-100$ & 5 \\
\hline R/V Meteor 26/1 & 1993 & September & N Atlantic & 47.8 & $19.8^{\circ} \mathrm{W}$ & $0-2000$ & 12 \\
\hline R/V Meteor 27/2 & 1994 & January & N Atlantic & $47-47.5$ & $17.5-18.5^{\circ} \mathrm{W}$ & $0-2500$ & 18 \\
\hline R/V Meteor 36/2 & 1996 & June & N Atlantic & 33 & $22^{\circ} \mathrm{W}$ & $60-80$ & 1 \\
\hline R/V Meteor 36/5 & 1996 & September & N Atlantic & $46-48.5$ & $17.5-22.3^{\circ} \mathrm{W}$ & $0-2500$ & 176 \\
\hline R/V Meteor 36/6 & 1996 & October & N Atlantic & 47.2 & $19.5^{\circ} \mathrm{W}$ & $0-2500$ & 26 \\
\hline FC Archipelago 3/97 & 1997 & August & N Atlantic & $32-35$ & $29.2-31.7^{\circ} \mathrm{W}$ & $0-1500$ & 26 \\
\hline R/V Poseidon 231/3 & 1997 & August & N Atlantic & $33-36$ & $22-30.8^{\circ} \mathrm{W}$ & $0-2500$ & 23 \\
\hline $\mathrm{R} / \mathrm{V}$ Meteor $42 / 3$ & 1998 & August & N Atlantic & $32.1-36$ & $28.9-31.6^{\circ} \mathrm{W}$ & $0-2500$ & 51 \\
\hline R/V Poseidon $247 / 2$ & 1999 & January & N Atlantic & $32.1-35.8$ & $20.5-31.6^{\circ} \mathrm{W}$ & $0-2500$ & 91 \\
\hline $\mathrm{R} / \mathrm{V}$ Meteor $35 / 1$ & 1996 & April-May & Caribbean & $12-19$ & $61.2-79.2^{\circ} \mathrm{W}$ & $0-2500$ & 129 \\
\hline R/V Meteor 31/2 & 1995 & February-March & Red Sea & $15.5-27.6$ & $34.5-41.7^{\circ} \mathrm{E}$ & $0-700$ & 50 \\
\hline $\mathrm{R} / \mathrm{V}$ Meteor $31 / 3$ & 1995 & March & Arabian Sea & 16.2 & $59.7^{\circ} \mathrm{E}$ & $0-2500$ & 32 \\
\hline $\mathrm{R} / \mathrm{V}$ Meteor $32 / 2$ & 1995 & May & Arabian Sea & 3 & $65^{\circ} \mathrm{E}$ & $0-2500$ & 13 \\
\hline R/V Meteor 32/5 & 1995 & August & Arabian Sea & 17.1 & $60^{\circ} \mathrm{E}$ & $0-100$ & 5 \\
\hline R/V Meteor 33/1 & 1995 & September-October & Arabian Sea & $10-16.1$ & $60.5-68.5^{\circ} \mathrm{E}$ & $0-2500$ & 53 \\
\hline R/V Sonne 117 & 1997 & March & Arabian Sea & $10-16.3$ & $60.3-65^{\circ} \mathrm{E}$ & $0-2500$ & 26 \\
\hline $\mathrm{R} / \mathrm{V}$ Sonne 118 & 1997 & April-May & Arabian Sea & $10-16.2$ & $60.2-65^{\circ} \mathrm{E}$ & $0-2500$ & 26 \\
\hline R/V Sonne 119 & 1997 & May-June & Arabian Sea & $10-20.5$ & $58.5-65^{\circ} \mathrm{E}$ & $0-2500$ & 25 \\
\hline Ortiz et al. (1995) & 1990 & September & NE Pacific & $41.5-42.2$ & $125.7-131.1^{\circ} \mathrm{W}$ & $0-200$ & 15 \\
\hline Kuroyanagi and Kawahata (2004) & 2002 & May-June & NW Pacific & $32.2-41.6$ & $131.7-143.4^{\circ} \mathrm{E}$ & $0-200$ & 56 \\
\hline
\end{tabular}

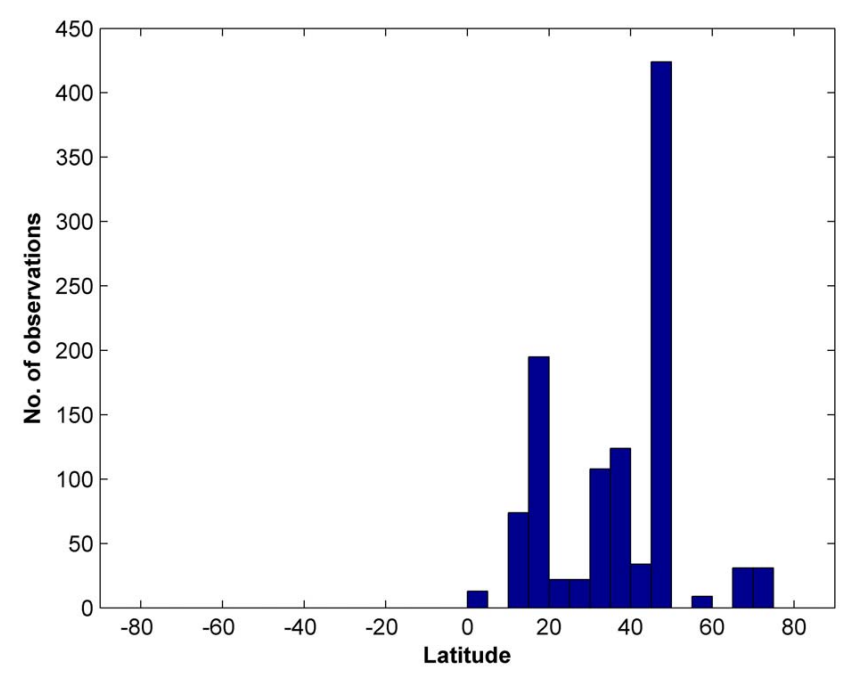

Figure 1. Latitudinal distribution (Northern Hemisphere) of the planktic foraminifer assemblage data. $n=1128$.

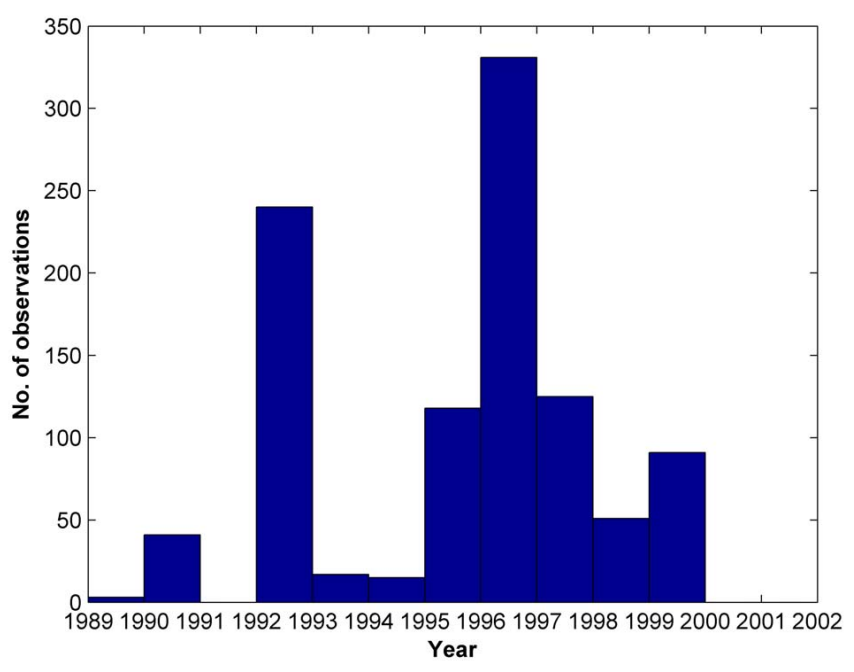

Figure 2. Distribution of the planktic foraminifer assemblage data according to year. $n=1128$. 
Table 2. Summary of 754 specimens of 21 planktic foraminifer taxa, ontogenetic stages (of $O$. universa), and 30 unidentified specimens analysed for their protein biomass from three cruises.

\begin{tabular}{|c|c|c|c|c|c|c|}
\hline Cruise & Year & Month & Location & $\begin{array}{l}\text { Water Depth } \\
\text { (m) }\end{array}$ & Taxa & $\begin{array}{l}\text { No. of } \\
\text { Specimens }\end{array}$ \\
\hline R/V Meteor $84 / 5$ & 2011 & June & Bay of Biscay & $0-100$ & Biorbulina sp. & 1 \\
\hline R/V Tansei-Maru KT11-20 & 2011 & August & NW Pacific & $0-500$ & Globigerina bulloides & 7 \\
\hline $\mathrm{R} / \mathrm{V}$ Meteor $84 / 5$ & 2011 & June & Bay of Biscay & $0-100$ & Globigerina falconensis & 2 \\
\hline R/V Poseidon 349 & 2007 & April & Azores & $500-700$ & Globigerinella calida & 1 \\
\hline R/V Meteor 84/5 & 2011 & June & Bay of Biscay & $0-100$ & Globigerinita glutinata & 7 \\
\hline R/V Poseidon 349 & 2007 & April & Azores & $0-700$ & Globigerinita glutinata & 6 \\
\hline R/V Meteor 84/5 & 2011 & June & Bay of Biscay & $0-100$ & Globigerinita uvula & 10 \\
\hline R/V Meteor 84/5 & 2011 & June & Bay of Biscay & $0-100$ & Globigerinoides sacculifer & 20 \\
\hline R/V Poseidon 349 & 2007 & April & Azores & $500-700$ & Globigerinoides sacculifer & 1 \\
\hline $\mathrm{R} / \mathrm{V}$ Meteor $84 / 5$ & 2011 & June & Bay of Biscay & $0-100$ & Globorotalia inflata & 69 \\
\hline R/V Tansei-Maru KT11-20 & 2011 & August & NW Pacific & $0-500$ & Globorotalia inflata & 8 \\
\hline R/V Poseidon 349 & 2007 & April & Azores & $100-1500$ & Globorotalia scitula & 26 \\
\hline R/V Poseidon 349 & 2007 & April & Azores & $100-700$ & Globorotalia truncatulinoides & 14 \\
\hline R/V Meteor 84/5 & 2011 & June & Bay of Biscay & $0-100$ & Hastigerina pelagica & 31 \\
\hline R/V Poseidon 349 & 2007 & April & Azores & $0-700$ & Hastigerina pelagica & 15 \\
\hline $\mathrm{R} / \mathrm{V}$ Meteor $84 / 5$ & 2011 & June & Bay of Biscay & $0-100$ & Neogloboquadrina dutertrei & 2 \\
\hline R/V Tansei-Maru KT11-20 & 2011 & August & NW Pacific & $0-500$ & Neogloboquadrina dutertrei & 8 \\
\hline $\mathrm{R} / \mathrm{V}$ Meteor $84 / 5$ & 2011 & June & Bay of Biscay & $0-100$ & Neogloboquadrina incompta & 20 \\
\hline R/V Tansei-Maru KT11-20 & 2011 & August & NW Pacific & $0-500$ & Neogloboquadrina incompta & 120 \\
\hline R/V Poseidon 349 & 2007 & April & Azores & $200-300$ & Neogloboquadrina incompta & 1 \\
\hline R/V Meteor $84 / 5$ & 2011 & June & Bay of Biscay & 1.5 & Tenuitella fleisheri & 1 \\
\hline R/V Meteor $84 / 5$ & 2011 & June & Bay of Biscay & $0-100$ & Turborotalita quinqueloba & 30 \\
\hline R/V Tansei-Maru KT11-20 & 2011 & August & NW Pacific & $0-200$ & Turborotalita quinqueloba & 5 \\
\hline
\end{tabular}

Kawahata (2004), from waters off Oregon (US) and Japan, respectively.

Planktic foraminifer protein-biomass was obtained from 754 individuals, including 21 species and morphotypes from all ontogenetic stages (Table 2). The average PFAB was calculated for average test-size frequencies in seven test-size bins (Table 3), and standing stocks at water-depths intervals between the surface ocean and $2500 \mathrm{~m}$ depth (Table 4). Construction of the data-set is explained in Fig. 3.

\subsection{Sampling and faunal counts}

A multinet with five $100-\mu \mathrm{m}$ and a rectangular opening of $0.25 \mathrm{~m}^{2}$ (HYDROBIOS midi ${ }^{\circledR}$ ) was applied for vertical hauls at $0.3-0.5 \mathrm{~m} \mathrm{~s}^{-1}$ towing speed (cf. Schiebel et al., 1995). Standardized water depth intervals of 0-20-40-6080-100-200-300-500-700-1000-1500-2000-2500 m allowed direct comparison of data from different sampling campaigns (Schiebel, 2002). Samples were preserved in a $4 \%$ formalinseawater solution and buffered with hexamine at a $\mathrm{pH}$ of 8.2. Classification and faunal counts were carried out on test size fractions $>100-125-150-200-250-315 \mu \mathrm{m}$ and $>315 \mu \mathrm{m}$ 
Table 3. Average protein-biomass (arithmetic mean) per planktic foraminifer test-size bin $(>100 \mu \mathrm{m})$, average frequency of specimens per size bin after Schiebel and Hemleben (2000), and protein content per size bin assuming average planktic foraminifer frequency.

\begin{tabular}{lcll}
\hline $\begin{array}{l}\text { Size bin } \\
(\mu \mathrm{m})\end{array}$ & $\begin{array}{c}\text { Average protein } \\
\text { biomass }(\mu \mathrm{g})\end{array}$ & $\begin{array}{l}\text { Average } \\
\text { frequency }(\%)\end{array}$ & $\begin{array}{l}\text { Biomass }(\mu \mathrm{g}) \\
\text { per size bin }\end{array}$ \\
\hline$>100-125$ & 0.700 & 50 & 0.35 \\
$>125-150$ & 0.700 & 25 & 0.175 \\
$>150-200$ & 0.838 & 12.5 & 0.10475 \\
$>200-250$ & 0.982 & 6.25 & 0.061375 \\
$>250-315$ & 1.540 & 3.125 & 0.048125 \\
$>315-400$ & 2.627 & 1.6 & 0.042032 \\
$>400-500$ & 3.416 & 0.8 & 0.027328 \\
$>500$ & 9.152 & 0.4 & 0.036608 \\
\hline Total & - & 99.675 & 0.845218 \\
\hline
\end{tabular}

with an incident binocular microscope using the taxonomy of Hemleben et al. (1989). Live individuals were differentiated from empty tests according to the presence or absence of cytoplasm, respectively. Daily to interannual data sets were combined, and regional data sets from different ocean basins were calibrated for their taxonomy and processing method. To avoid bias in the faunal data resulting from possible under-sampling close to the mesh-size $(100 \mu \mathrm{m})$ of the plankton net, the faunal data analysed here $(n=6100)$ refer to the size fraction $>125 \mu \mathrm{m}$. Census data are available from the Pangaea database (Bremerhaven, Germany, www.pangaea.de).

\subsection{Protein measurement}

\subsubsection{Sampling of live planktic foraminifers for protein measurement}

Live planktic foraminifers were sampled on three researchcruises in the subtropical to temperate eastern North Atlantic and temperate western North Pacific (Table 2). From R/V Poseidon cruise 349 in waters off the Azores Islands from 5 to 24 April, 2007, 133 live specimens of planktic foraminifers from seven stations were sampled from discrete water depth intervals, classified, and deep-frozen individually before analyses in the laboratory. From the R/V Meteor cruise 84/5, 31 May to 21 June 2011, in the Bay of Biscay, 413 live planktic foraminifers were analysed. From the R/V Tansei-Maru cruise KT11-20, 21-25 August 2011, in the Pacific off northeastern Honshu, Japan, 213 live foraminifers were analysed. Specimens sampled during the latter two cruises were analysed for their protein content on board the research vessel immediately after sampling. Analyses of the test morphometry and weight were carried out at the University of Angers.

A total of 754 foraminifers were analysed from 18 sites and water depths ranging from 0 to $1500 \mathrm{~m}$ (Table 2). Specimens were classified and processed individually. Each

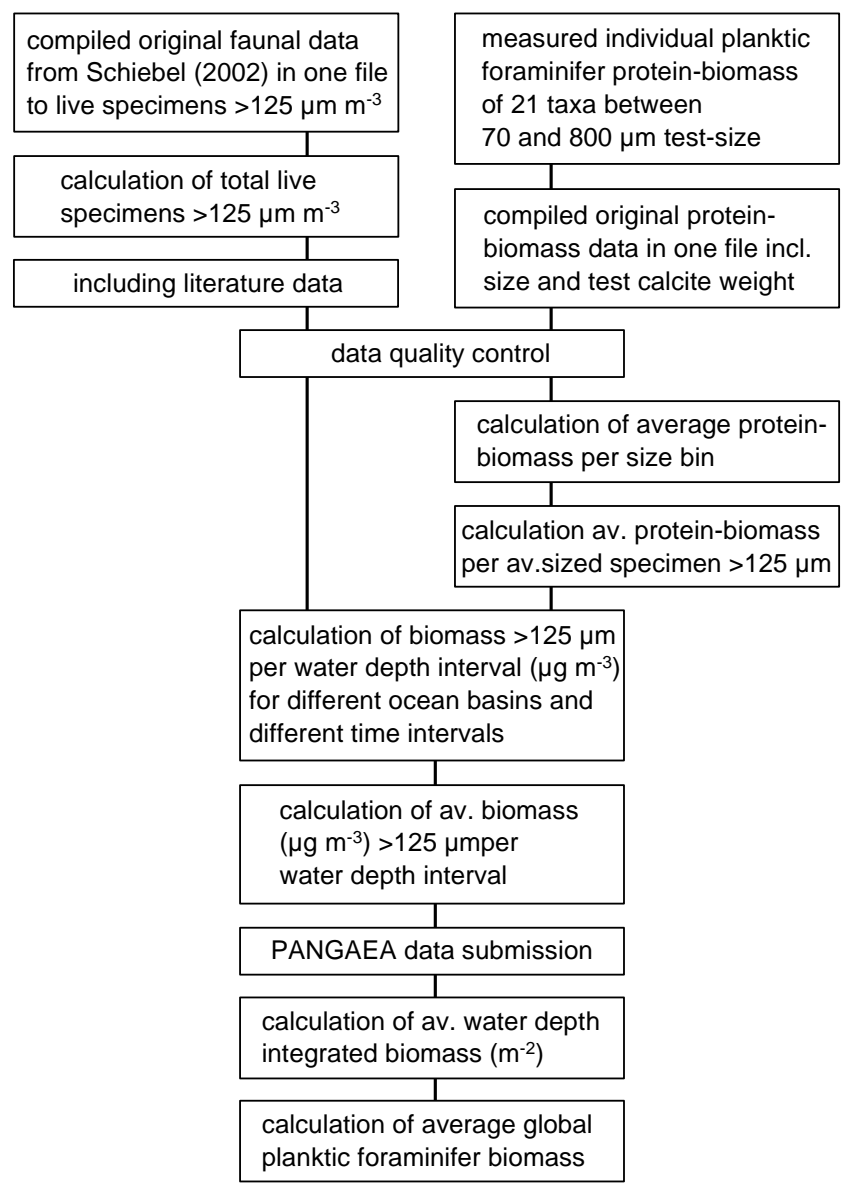

Figure 3. Flow chart of the methodology used to construct a data set on planktic foraminifer biomass estimates from abundance data from www.pangaea.de (Schiebel, 2002), Ortiz et al. (1995), Kuroyanagi and Kawahata (2004), and individual species protein-biomass data.

foraminifer was transferred into a bath of micro-filtered seawater, gently cleaned with a brush to remove all particles stuck to the specimen including organic matter. Subsequently, specimens were immersed in deionized water for less than a second to remove the seawater. Each foraminifer was individually stored in an Eppendorf cup, and frozen at $-80^{\circ} \mathrm{C}$ (R/V Poseidon 349), or immediately analysed for protein content (R/V Meteor 84/5 and Tansei-Maru KT1120).

\subsubsection{Planktic foraminifer protein analyses using nano-spectrophotometry}

Protein-biomass of planktic foraminifers was analysed with the bicinchoninic acid (BCA) method developed by Smith (1985), using a mix of copper solution $(4 \%(w / v)$ $\mathrm{CuSO}_{4} 5 \mathrm{H}_{2} \mathrm{O}$ solution; Sigma-Aldrich) and BCA (Sigma) solution (Smith et al., 1985; Zubkov and Sleigh, 1999; Mojtahid et al., 2011). In contact with proteins the $\mathrm{Cu}^{2+}$ ions of 
Table 4. Average (arithmetic mean and geometric mean) planktic foraminifer $(>125 \mu \mathrm{m})$ protein biomass $\mathrm{m}^{-3}$, and integrated over water

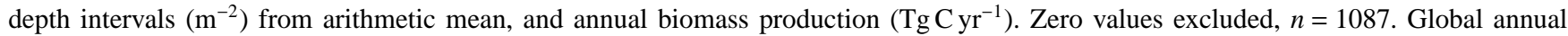
biomass production is given for $322 \times 10^{6} \mathrm{~km}^{2}$ and 9 month $\mathrm{yr}^{-1}$.

\begin{tabular}{|c|c|c|c|c|}
\hline Water depth (m) & $\begin{array}{l}\text { Protein biomass } \\
\left(\mu \mathrm{g} \mathrm{m}^{-3}\right) \text { arithmetic }\end{array}$ & $\begin{array}{l}\text { Protein biomass* } \\
\left(\mu \mathrm{g} \mathrm{m}^{-2}\right)\end{array}$ & $\begin{array}{l}\text { Protein biomass } \\
\left(\mu \mathrm{g} \mathrm{m}^{-3}\right) \text { geometric }\end{array}$ & $\begin{array}{l}\text { Protein biomass** } \\
\left(\mu \mathrm{g} \mathrm{m}^{-2}\right)\end{array}$ \\
\hline 0-20 & $70.04(29.94-135.74)$ & 1400.80 & 27.69 & 553.83 \\
\hline $20-40$ & $51.54(22.50-85.82)$ & 1030.77 & 20.07 & 401.32 \\
\hline $40-60$ & $51.09(22.77-89.19)$ & 1021.71 & 16.48 & 329.50 \\
\hline $60-80$ & $46.44(16.74-84.69)$ & 928.73 & 9.87 & 197.36 \\
\hline $80-100$ & $37.48(12.29-66.26)$ & 749.57 & 8.03 & 160.64 \\
\hline $100-200$ & $26.40(7.34-44.51)$ & 2640.20 & 3.90 & 390.14 \\
\hline $200-300$ & $11.16(2.81-14.87)$ & 1116.19 & 2.04 & 204.07 \\
\hline $300-500$ & $4.52 \quad(1.34-5.00)$ & 903.24 & 1.02 & 203.02 \\
\hline $500-700$ & $3.08 \quad(0.89-3.32)$ & 616.36 & 0.60 & 120.79 \\
\hline $700-1000$ & $0.96 \quad(0.37-0.98)$ & 289.03 & 0.39 & 117.83 \\
\hline $1000-1500$ & $0.42 \quad(0.16-0.42)$ & 208.71 & 0.18 & 92.28 \\
\hline $1500-2000$ & $0.34 \quad(0.15-0.34)$ & 169.20 & 0.16 & 81.40 \\
\hline $2000-2500$ & $0.38 \quad(0.14-0.38)$ & 190.62 & 0.16 & 81.93 \\
\hline Total & - & 11265.13 & - & 2934.11 \\
\hline Global (Tg C yr ${ }^{-1}$ ) & - & $32.7(11.1-51.3)$ & - & 8.5 \\
\hline
\end{tabular}

* From mean arithmetic mean, ${ }^{* *}$ from geometric mean.

the copper solution are reduced to $\mathrm{Cu}^{+}$. The $\mathrm{Cu}^{+}$ions react with the BCA, and a strong purple color is produced. The intensity of the color increases proportionally with the protein concentration, and the absorbance of the $562 \mathrm{~nm}$ wave length was measured with a nano-spectrophotometer on $2 \mu \mathrm{l}$ of sample or standard solution (NanoDrop $2000^{\circledR}$, Thermo Scientific). Protein standard solution consists of bovine serum albumin (BSA) of known concentration. Each sample and standard solution was measured in triplicate (Movellan et al., 2012). Foraminifer samples and protein standard solutions were prepared at the same time to make sure that the incubation time and temperature were identical.

Immediately after the foraminifers were cleaned and stored in Eppendorf cups (Meteor 84/5 and Tansei-Maru KT11-20), or after being unfrozen in the case of the R/V Poseidon 349 samples, $20 \mu \mathrm{l}$ micro-filtered tap water was added to each Eppendorf cup for 30 min to allow for an osmotic shock to quantitatively expose the foraminifer cytoplasm, and $400 \mu \mathrm{l}$ of working reagent (WR) was added (Movellan et al., 2012).

The reaction and resulting coloration of the sample solution depends on incubation time and temperature, which was adjusted to the foraminifer protein contents. An optimum color spectrum was obtained at an incubation time of $24 \mathrm{~h}$ at room temperature $\left(20 \pm 2{ }^{\circ} \mathrm{C}\right)$. After incubation, each tube was centrifuged for 3 seconds at $5000 \mathrm{rpm}$, and the absorbance at $562 \mathrm{~nm}$ was measured with a NanoDrop $200{ }^{\circledR}$ nano-spectrophotometer. The absorbance of the WR is affected both by color and brightness resulting from the concentration of proteins. Each absorbance value was mea- sured three times, and standard curves were constructed using polynomial regression.

The efficiency and yield of the osmotic shock method for cytoplasm exposure was tested on 24 specimens of Globorotalia hirsuta, Globorotalia scitula, and Globigerinella siphonifera from the R/V Poseidon 349 samples. The three species were chosen for their different test architectures and apertures, i.e. globular with wide apertures (G. siphonifera), discoidal with intermediate-sized apertures (G. hirsuta), and discoidal with small apertures (G. scitula). Cytoplasm and proteins were exposed to the WR by crushing the foraminifer tests, and compared to specimens from the same populations, which were subjected to an osmotic shock (not crushed) for cytoplasm exposure.

\subsection{Morphometric analyses and weight of the foraminifer test}

After protein analyses, the foraminifer tests were carefully cleaned with tap water to remove particles and stains of the WR. The tests were then stored individually in micro-slides. Each test was photographed from the apertural side with an automated incident light microscope installed at the University of Angers, and driven by analySIS ${ }^{\circledR}$ software (Bollmann et al., 2004; Clayton et al., 2009), at a resolution of $1.4 \mu \mathrm{m}^{2}$ (pixel size), and images were analysed for their twodimensional (silhouette) morphometry. Minimum diameter and silhouette area were used for analyses of the protein-tosize relation of the planktic foraminifer tests (Figs. 4 and 5).

A microbalance (Mettler Toledo XP2U, readability of $0.1 \mu \mathrm{g}$ ) was employed to weigh individual foraminifer tests. 

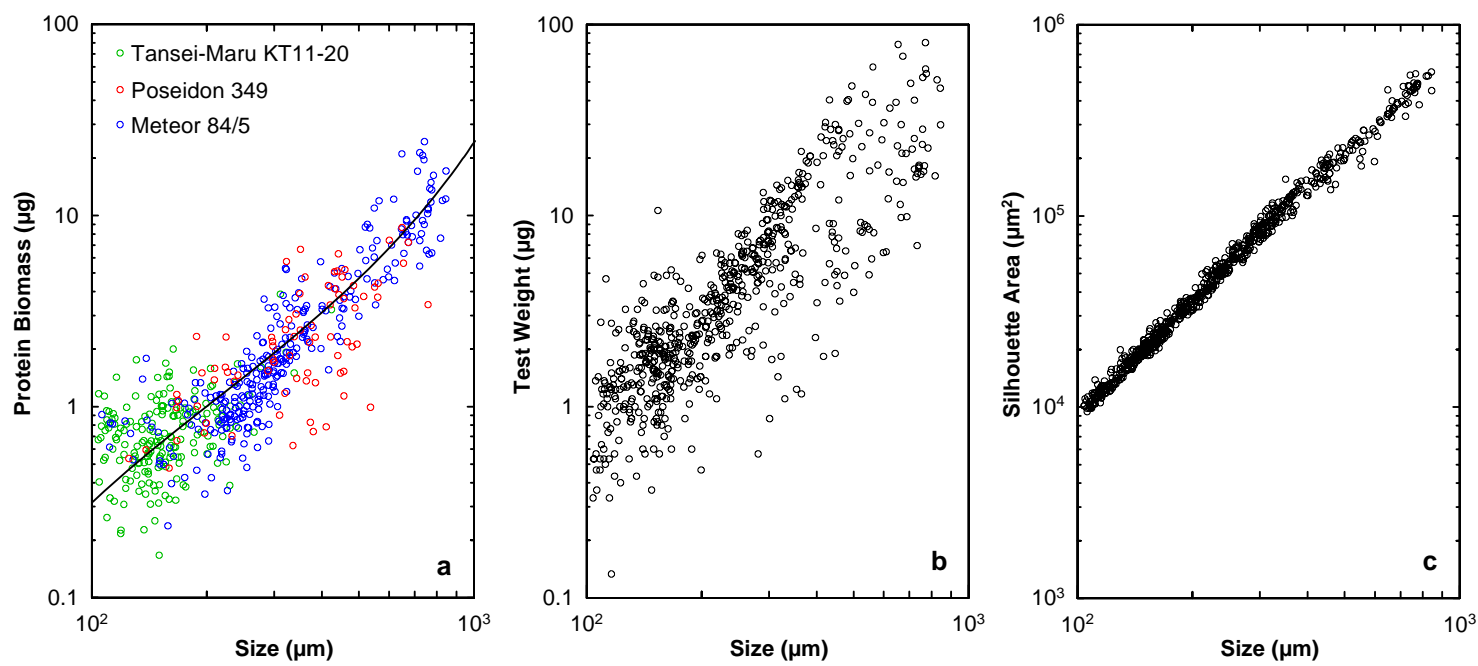

Figure 4. (a) Variation of planktic foraminifer protein content with size (minimum diameter) at the Bay of Biscay (R/V Meteor 84/5), the Azores region (R/V Poseidon 349), and the western Pacific (R/V Tansei-Maru KT11-20). $n=561, r^{2}=0.745$ (exponential fit), $p<0.00001$, standard deviation of the residuals $=1.612$. (b) Variation of test weight with size (minimum diameter) of the total data set $(n=646)$. Different size-to-weight ratios of different species result in a low $r^{2}=0.571$ (linear fit), $p<0.00001$, standard deviation of the residuals $=6.623$. (c) Relation of size (minimum diameter) and silhouette area, the latter of which has been shown to constrain size-and-weight changes to a high degree (Beer et al., 2010): $n=660, r^{2}=0.974, p<0.00001$.

Weighing was carried out in an air-conditioned weighingroom at constant temperature and humidity. Each foraminifer was individually stored in an aluminium capsule and weighed after $>12 \mathrm{~h}$ of acclimatisation in the weighing room. All foraminifer tests were weighed three times, at an overall average precision of $\pm 0.17 \mu \mathrm{g}$.

\subsection{Quality control}

Most of the data points on planktic-foraminifer assemblagebiomass (PFAB) presented here are calculated from own data on population dynamics (faunal data, standing stocks), and individual protein-biomass data. All of our own data points on standing stocks and protein-biomass were individually verified. In case any data point deviated from data points of similar context, i.e. protein-biomass data from similar species and size, and faunal data from similar locations and water depths, those data were rejected (6 out of 762). All zero values (i.e. empty tests) were removed from the individual protein-biomass data, as well as protein-biomass values, which were unreasonable considering the size and test-weight of a species. In turn, zero values were kept in the data set on standing stocks, since the water column (in particular at greater depth) can be devoid of live planktic foraminifers. We did not apply Chauvenet's criterion to remove outliers from our data set, because (i) we could verify all of the data presented here, which were all produced at our laboratory and assumed reliable, and (ii) the maximum values are included in the natural variability of standing stocks and assemblage-biomass. In addition to own data, we have carefully chosen literature data of similar sampling (i.e. gear, depth intervals, and live specimens $>125-\mu \mathrm{m}$ test-size) and storing method (buffered formaldehyde). All of those criteria could be applied to the data of Kuroyanagi and Kawahata (2004) and Ortiz et al. (1995).

\section{Results}

\subsection{Efficiency of the BCA method for planktic foraminifer protein-biomass determination}

The protein data derived from specimens treated with an osmotic shock (standard method) were compared to data from 24 crushed specimens of G. hirsuta, G. scitula, and G. siphonifera from the same samples (R/V Poseidon 349) using variance analysis (performed with the software $\mathrm{R}$ v.12.2.1). The protein contents of crushed specimens of G. hirsuta and $G$. siphonifera are not significantly different from the specimens submitted to an osmotic shock ( $p=0.5929$ and 0.3312 , respectively). We hence conclude that the standard BCA method (i.e. osmotic shock) provides reliable protein data for these two species representative of all species of the data set including 704 individuals (i.e. $94.7 \%$ of the data set on protein-biomass; Table 2). In contrast, the protein content of $G$. scitula was significantly larger for crushed specimens (average $2.416 \mu \mathrm{g}$ ) than for the specimens subjected to an osmotic shock (average $2.238 \mu \mathrm{g} ; p=0.02465$ ), i.e. the method resulted in a yield $92.59 \%$. The slight underestimation of the measured protein content of $G$. scitula using the osmotic shock method may results from the compact test architecture and the small aperture of this small globorotalid species. The 


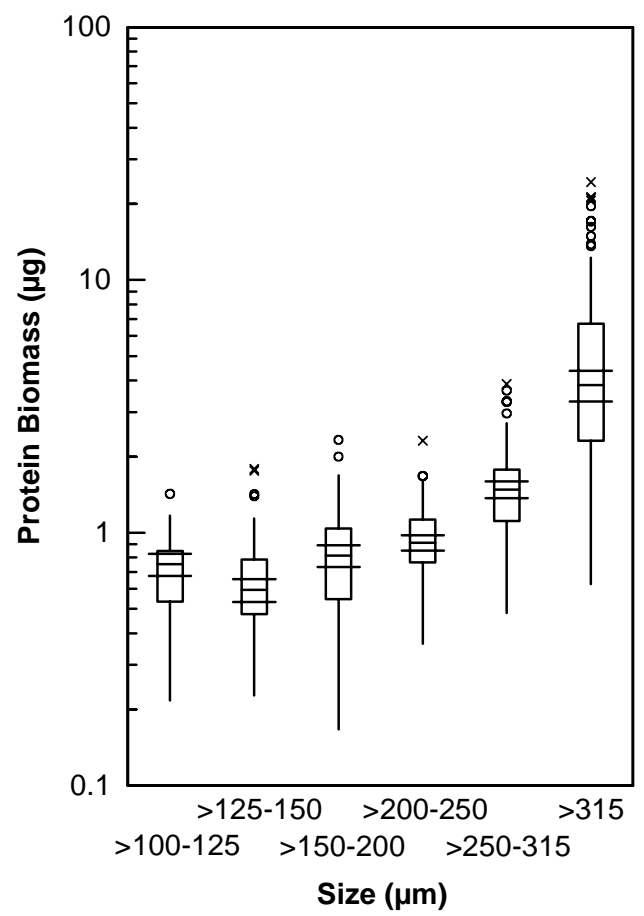

Figure 5. Average protein-biomass versus minimum diameter displayed as median values, notches, and the upper and lower quartiles for the respective size bins. The arithmetic mean of protein-biomass of the two smallest size bins is similar at $0.7 \mu \mathrm{g} \mathrm{C}$ per specimen. Circles and crosses indicate outside and far outside values, respectively.

same might be true for the globorotalid species G. truncatulinoides. Since both species G. scitula and G. truncatulinoides include only $5.3 \%$ of the biomass data set, and $<1 \%$ of the faunal data, we did not correct the following assemblagebiomass calculations for this bias.

\subsection{Planktic foraminifer biomass, test size, and weight}

Individual planktic foraminifer biomass is related to test size (Fig. 4). In turn, the size-normalised protein-biomass of different species, and the planktic-foraminifer assemblagebiomass (PFAB) from different latitudes (Fig. 6) and different months and seasons (Fig. 7) are similar. The average proteinbiomass of the two smallest planktic foraminifer test size bins $>100-125 \mu \mathrm{m}$ and $>125-150 \mu \mathrm{m}$ is similar at $0.7 \mu \mathrm{g}$ per specimen (Table 3 ), and significantly ( $t_{99}$ ) increases in the larger size bins (Table 3, Fig. 5). In turn, the small size bins contribute more to the PFAB (Table 3) because of a much higher frequency of small than large specimens to the overall standing stocks (Peeters et al., 1999; Schiebel and Hemleben, 2000). The average global individual planktic foraminifer protein-biomass is calculated at $0.845 \mu \mathrm{g}$ (Table 3).

PFAB as a function of water depth is highest in the upper $60 \mathrm{~m}$ of the water column, and decreases by two orders

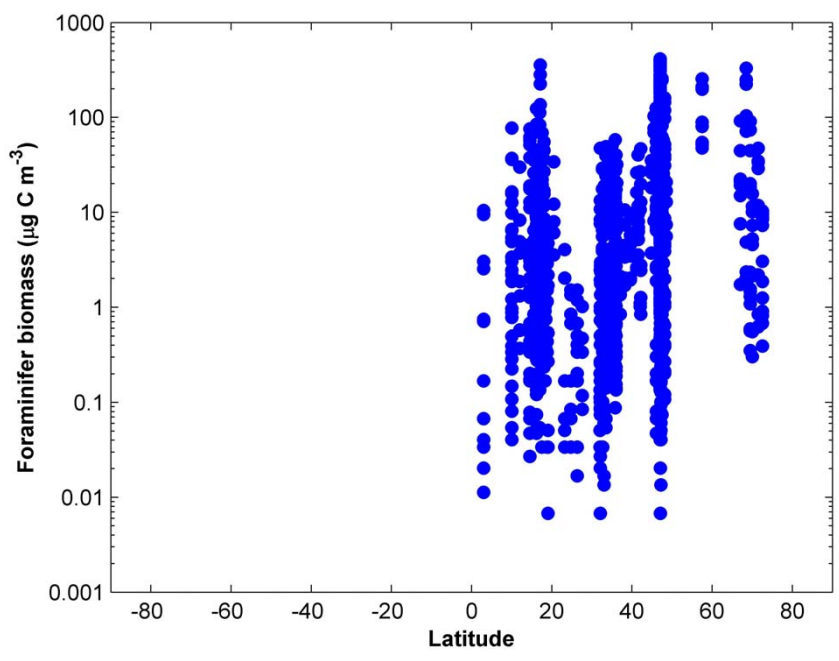

Figure 6. Distribution of log-normalised planktic foraminifer cytoplasm-carbon biomass $\left(\log _{10} \mu \mathrm{g} \mathrm{C} \mathrm{m}^{-3}\right)$ as a function of latitude ( $n=1016$; without zero values).

of magnitude to a water depth of $1000 \mathrm{~m}$ (Table 4, Fig. 8). The highest variation in individual protein-biomass occurs at intermediate water depths from 100-700 m (Fig. 8). In turn, species- and size-specific individual biomass is not related to water depth, as shown for Globorotalia hirsuta (Fig. 9). The average global depth-integrated protein-biomass of planktic foraminifers per square meter down to $2500 \mathrm{~m}$ water depth is $11.27 \mathrm{mg}$ (Table 4).

The $\mathrm{CaCO}_{3}$ mass (i.e. weight) of planktic foraminifer tests analysed here was on average three times as high as the protein-biomass (Fig. 4a and b). Given a theoretical $\mathrm{CaCO}_{3}$ mass of planktic foraminifer tests of $100.09 \mathrm{~g} \mathrm{~mol}^{-1}$, and a calcite-carbon mass of $12.01 \mathrm{~g} \mathrm{~mol}^{-1}$, the planktic foraminifer test calcite-carbon mass resembles $\sim 36 \%$ of the protein-biomass, but which is not included in the biomass data presented in the following.

\subsection{Seasonal development of the planktic-foraminifer assemblage-biomass (PFAB)}

Seasonal changes in PFAB are most pronounced in surface waters. The highest PFAB in the temperate North Atlantic at BIOTRANS (around $47^{\circ} \mathrm{N}, 20^{\circ} \mathrm{W}$ ) occurred in spring (March and April), and affected waters down to $300 \mathrm{~m}$ water depth (Fig. 10). Intermediate PFAB occurred in surface waters during summer, and lowest PFAB occurred in surface and deep waters in fall and later winter (Fig. 10).

Highest PFAB in the Arabian Sea occurred in July and August, i.e. during the fully developed SW monsoon (Fig. 11), with concentrations similar to those during spring in the North Atlantic (Fig. 10). In contrast to the North Atlantic, very high PFAB in the Arabian Sea was more restricted to the surface $100 \mathrm{~m}$ of the water column (Fig. 11). Lowest PFAB in the Arabian Sea occurred in late March to April, i.e. during 


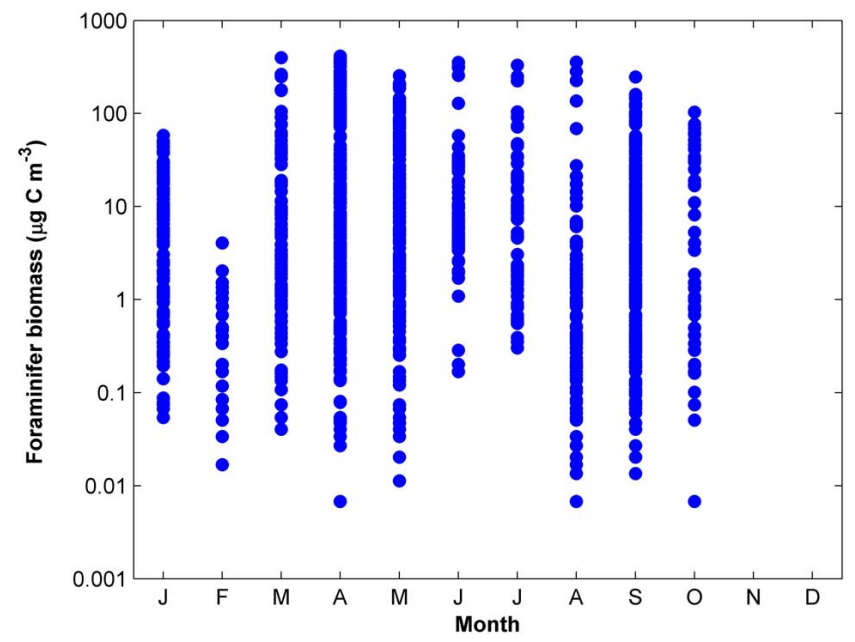

Figure 7. Distribution of log-normalised planktic foraminifer cytoplasm-carbon biomass $\left(\log _{10} \mu \mathrm{g} \mathrm{C} \mathrm{m}^{-3}\right)$ as a function of time, i.e. months and Northern Hemisphere seasons $(n=1087$; without zero values).

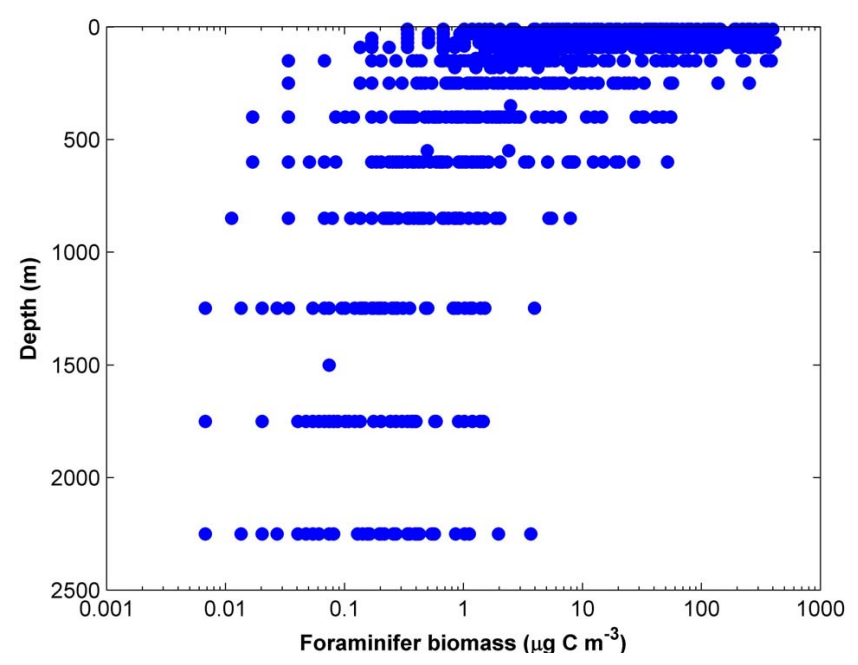

Figure 8. Log-normalised carbon-biomass $\left(\log _{10} \mu \mathrm{g} \mathrm{m}^{-3}\right)$ given for the total planktic foraminifer assemblage $>125 \mu \mathrm{m}$ (http://doi. pangaea.de/10.1594/PANGAEA.777386). Data are calculated from average individual protein-biomass data and faunal counts from the eastern North Atlantic, Caribbean, and Arabian Sea $(n=1087$; without zero values). All data given for the mid-points of the sampled water depth intervals. The assemblage protein-biomass data of surface and deep waters cover about three orders of magnitude, and five orders of magnitude of variation in intermediate water depths (i.e. $100-500 \mathrm{~m}$ ).

the spring intermonsoon. During the late NE monsoon (early to mid March), PFAB in the Arabian Sea was slightly higher than during the intermonsoon (Fig. 11).

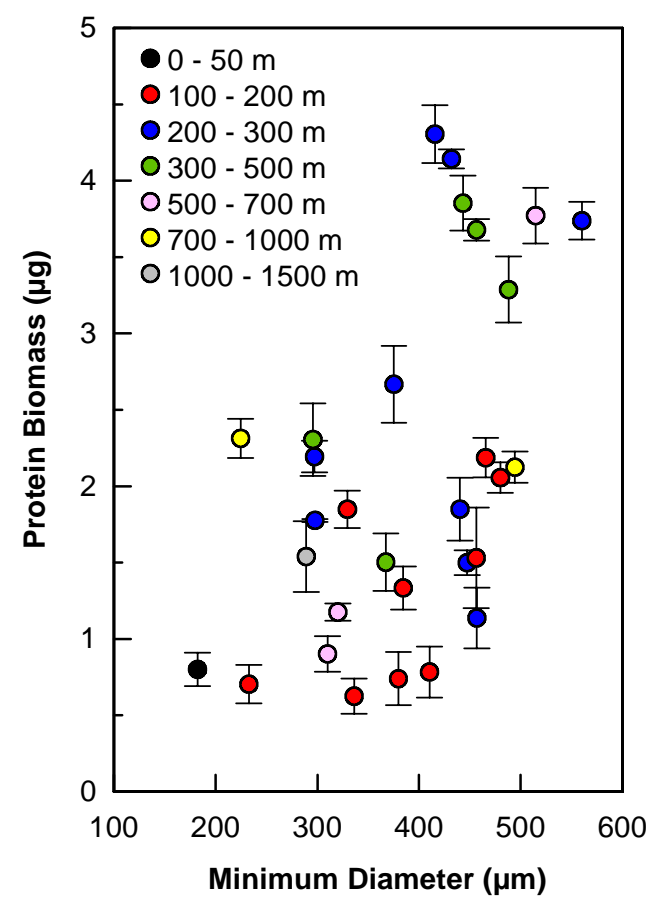

Figure 9. Protein-biomass of Globorotalia hirsuta from different water depth is largest between $200-700 \mathrm{~m}$ water depth, but is in general rather correlated to individual size $(n=30)$. The largest individuals (adults) are known to dwell at subsurface depth. Globorotalia hirsuta has been selected for the analyses of depth dependant biomass changes because the species frequently occurs over a large water depth interval and are easily analysed for their protein content.

\subsection{Regional differences in PFAB}

Lowest average PFAB occurred in the subtropical North Atlantic, in the central and equatorial Arabian Sea, and in the Red Sea (Fig. 12). Average PFAB in the subtropical gyre south of the Azores Islands in the eastern North Atlantic was one order of magnitude lower than the PFAB at mid-latitudes (Fig. 12). The further north in the eastern North Atlantic the more limited is the PFAB to the short productive season. The maximum PFAB concentration of $>200 \mu \mathrm{g} \mathrm{m}^{-3}$ at $68^{\circ} \mathrm{N}$ in July was quantitatively similar to that in spring at $47^{\circ} \mathrm{N}$ (Fig. 12). Highest PFAB concentration of $>100 \mu \mathrm{g} \mathrm{m}^{-3}$ in the Arabian Sea around $17^{\circ} \mathrm{N}, 60^{\circ} \mathrm{E}$ occurred in surface waters at the upwelling region off Oman, and affected also the subsurface (>100 m depth) water column (Figs. 11 and 12). PFABs in the eastern and western Pacific range at medium values in comparison to PFABs in the Atlantic and Arabian Sea. In general, average PFAB exponentially decreases with water depth between 100-1500 m (Fig. 8) in regions and during times of low biological productivity, and is enhanced down to water depth $>1000 \mathrm{~m}$ in regions and at times of high productivity (Figs. 10 to 12 ). 


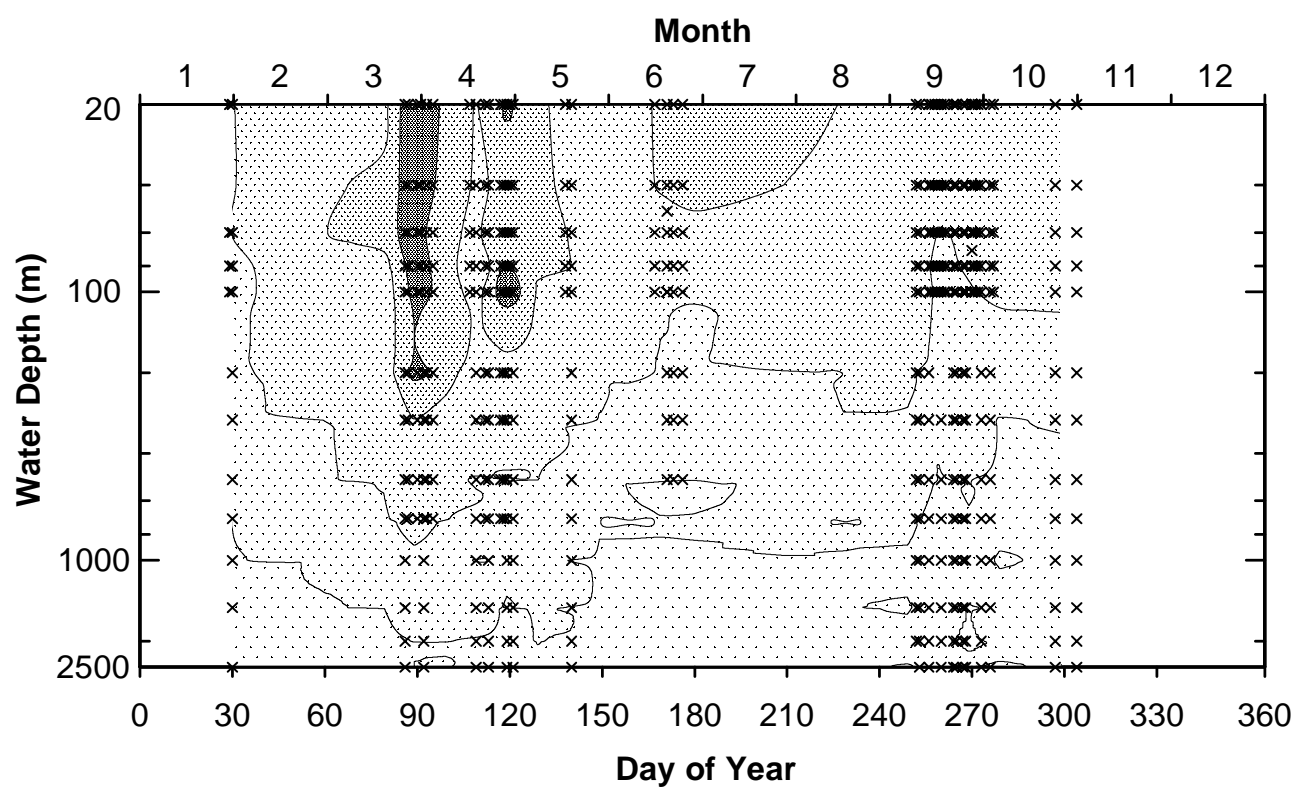

Figure 10. Average temporal development of planktic foraminifer assemblage $>125 \mu \mathrm{m}$ protein-biomass at BIOTRANS, North Atlantic at $47^{\circ} \mathrm{N}, 20^{\circ} \mathrm{W} . n=428$ data points $(0-2500 \mathrm{~m})$ between 1990 and 1996 (Table 1$)$. Water depths refer to the lower limits of the sampled water depth intervals. Grey levels correspond to $>200,>100-200,>10-100,>1-10,>0-1$, and $0 \mu \mathrm{g} \mathrm{Cm}^{-3}$. White $=$ time interval not sampled. Resolution: $z=20 \mathrm{~m}$ water depth, $t=10$ days, using quadrant interpolation.

\section{Biomass conversion factors}

The protein-biomass of planktic foraminifers measured by nano-spectrophotometry, and the resulting biomass conversion factors calculated from our data are similar to those given by Michaels et al. (1995) from CHN analysis. An average species of 315- $\mu \mathrm{m}$ minimum test diameter contains about $2.2 \mu \mathrm{g}$ protein-biomass (Fig. 4a), which amounts to $2.2 \mu \mathrm{g}$ per $10^{5} \mu \mathrm{m}^{2}$ silhouette area (Fig. $4 \mathrm{~b}$ ), the latter being a reliable measure of the foraminifer test volume (Beer et al., 2010). The resulting conversion factor between biomass

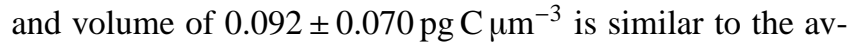
erage value of $0.089 \pm 0.055{\mathrm{pg} \mathrm{C} \mathrm{m}^{-3}}^{-3}$ given by Michaels et al. (1995) without specifying the size of the analysed specimens. However, Michaels et al. (1995) analysed the same species $O$. universa and $H$. pelagica, which are also frequent in our data on larger subtropical species (Table 2). Based on this inter-comparison, we conclude that the protein-biomass equals the amount of cytoplasm carbon (see also Zubkov et al., 1999, on bacteria). In addition, CHN data on the (benthic) foraminifer Ammonia tepida indicate that foraminifer protein-biomass equals carbon-biomass (Movellan, 2012).

Smaller planktic foraminifer specimens have much higher average conversion factors of $0.413 \pm 0.040 \mathrm{pg} \mathrm{C} \mathrm{m}^{-3}$ (at $100 \mu \mathrm{m}$ minimum test diameter) than larger specimens (deduced from Fig. 4a and b). Consequently, we have based our biomass calculations on average biomass conversion factors for different test-size bins (Table 3), resembling those also applied to the analyses of the live planktic foraminifer popu- lation dynamics (e.g. Schiebel and Hemleben, 2000). We assume that the individual planktic foraminifer cytoplasm (including the reticulate and rhizopodial cytoplasm) was quantitatively sampled, and we do not account for any symbiontbiomass. Individual planktic foraminifer biomass appears to be independent of water depth (Fig. 9), though, and the same biomass conversion factors per size bin are applied to all analysed water depth intervals (Table 4).

\subsection{First-order estimates of the global planktic foraminifer biomass stock and biomass production}

The majority of planktic foraminifers is living in the surface oceans, hemipelagic oeans, and marginal ocean basin (e.g. Vincent and Berger, 1981; Schiebel et al., 1995; Peeters and Brummer, 2002; Kuroyanagi and Kawahata, 2004; Loncaric et al., 2006; Retailleau et al., 2011), i.e. above and within the seasonal pycnocline and associated deep chlorophyll maximum (DCM). Accordingly, the largest regional and temporal variation in population dynamics occurs in surface waters (Schiebel, 2002). Diversity and turnover rates of the subsurface and deep dwelling fauna are much smaller than those of the surface dwelling fauna (Schiebel and Hemleben, 2005). Consequently, our calculation of the surface water PFAB is based on a data set of higher resolution than that of the subsurface to deep PFAB (Tables 1 and 2, Fig. 8).

Our data on the planktic foraminifer population dynamics in the eastern North Atlantic, Caribbean, Red Sea, and Arabian Sea (Table 1) cover a wide range of productivity regimes (Berger et al., 1988; Berger, 1989; Yoder et al., 1993; Antoine 


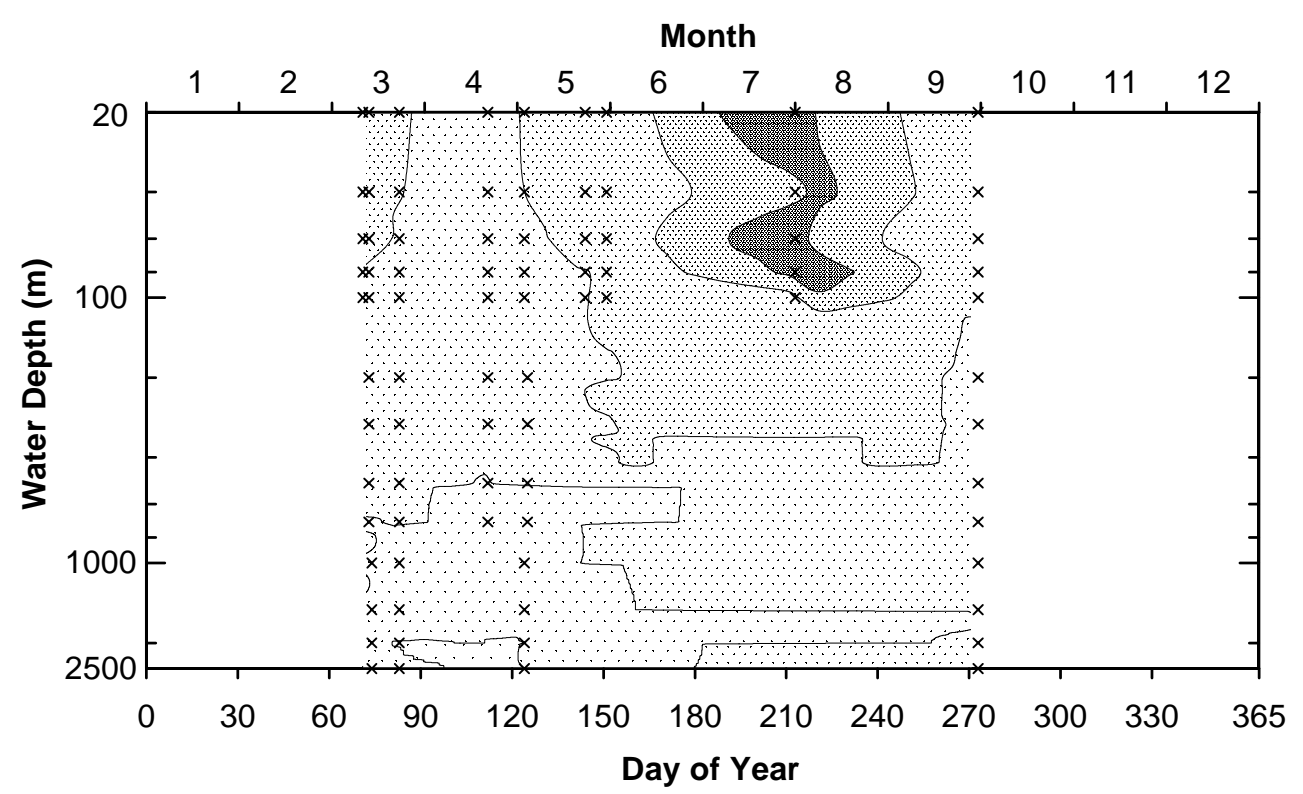

Figure 11. Average temporal development of planktic foraminifer assemblage $>125 \mu \mathrm{m}$ protein-biomass at WAST, Arabian Sea at $20^{\circ} \mathrm{N}$, $60^{\circ}$ E. $n=80$ data points (0-2500 m water depth) in 1995 and 1997 (Table 1). Water depths refer to the lower limits of the sampled water depth intervals. Gray levels correspond to $>200,>100-200,>10-100,>1-10,>0-1$, and $0 \mu \mathrm{g} \mathrm{C} \mathrm{m}^{-3}$. White $=$ time interval not sampled. Resolution: $z=20 \mathrm{~m}$ water depth, $t=10$ days, using quadrant interpolation.

et al., 1996; Longhurst, 2007; the MODIS web site) from equatorial to subpolar latitudes, including oligotrophic waters of the subtropical gyres and upwelling regions (Fig. 12), and facilitate a first-order estimate of the global planktic foraminiferal biomass. However, being omnivorous zooplankton, the production of planktic foraminifers is not directly related to primary production (Schiebel, 2002). We have hence calculated the PFAB from regional data sets on population dynamics (numbers per $\mathrm{m}^{3}$ ) available from http://doi.pangaea.de/10.1594/PANGAEA.777386.

Considering the good data coverage between the tropical and polar oceans (Figs. 1 and 6), oligotrophic to eutrophic waters (Fig. 12; cf. Schiebel, 2002), and over the productive seasons (Fig. 7; cf. Obata et al., 1996, for seasonal changes in the surface ocean productivity) between 1989 and 1999 (Fig. 2), the average PFAB $>125 \mu \mathrm{m}$ test-size sums up to a global average of 2.93-11.27 $\mathrm{mg} \mathrm{C} \mathrm{m}^{-2}$ (geometric mean and arithmetic mean, respectively) at any point of time (Table 4 : 2934.11-11265.13 $\mu \mathrm{g} \mathrm{C} \mathrm{m}^{-2}$ ). Planktic foraminifer biomass at waters deeper than $2500 \mathrm{~m}$ is assumed negligible here (cf. Schiebel, 2002).

To extrapolate from regional to global planktic foraminifer biomass, the absolute surface area of the global deep ocean is taken as $290 \times 10^{6} \mathrm{~km}^{2}$ (Milliman and Droxler, 1996; total area $=362.03 \times 10^{6} \mathrm{~km}^{2}$, cf. Dietrich et al., 1975). This excludes areas of the global ocean, in which planktic foraminifer reproduction, and hence foraminifer production, is supposed to be inhibited due to, for example, shallow water depths, turbidity of the ambient seawater, or ice cover (Hem- leben et al., 1989). The resulting global planktic foraminifer biomass would hence add up to $0.85-3.27 \mathrm{Tg} \mathrm{C}$ at any point of time. Assuming a global deep ocean surface of $290 \times$ $10^{6} \mathrm{~km}^{2}$ inhabited by fully developed planktic foraminifer faunas might be a rather conservative guess, though, since Retailleau et al. $(2009,2011)$ presented fully developed faunas in the marginal Bay of Biscay, like in all other marginal basins included in our estimate. Including marginal basins increases the ocean area inhabited by planktic foraminifers by $32 \times 10^{6} \mathrm{~km}^{2}$ to $322 \times 10^{6} \mathrm{~km}^{2}$ (Milliman and Droxler, 1996), resulting in a global planktic foraminifer biomass of 0.94$3.63 \mathrm{Tg} \mathrm{C}$ at any point of time.

The average turnover time, i.e. the synodic lunar reproduction cycle of surface dwelling planktic foraminifer species is assumed to be one month (e.g. Schiebel and Hemleben, 2005, and references therein). The abundant shallow dwelling species Globigerinoides ruber (fortnightly reproduction) and possibly all deep dwelling globorotalids (up to annual reproduction cycles) are exceptions. Excluding aphotic (winter) conditions in mid to high latitudes, and assuming nine complete reproduction cycles per year on average, the global planktic foraminifer biomass production $\left(>125 \mu \mathrm{m}\right.$ ) amounts to $8.5-32.7 \mathrm{Tg} \mathrm{C} \mathrm{yr}^{-1}$ (geometric mean and arithmetic mean, respectively; Table 4). Interannual variations in regional planktic foraminifer production (Schiebel and Hemleben, 2000) are assumed compensated at the global scale.

The above calculations include only the planktic foraminifer fauna $>125 \mu \mathrm{m}$, though, excluding smaller 
(a)

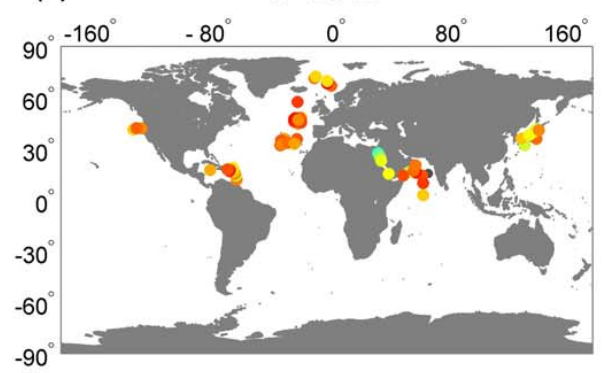

(c)

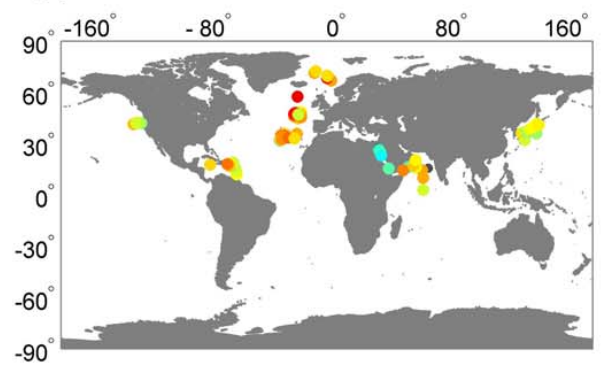

(e)

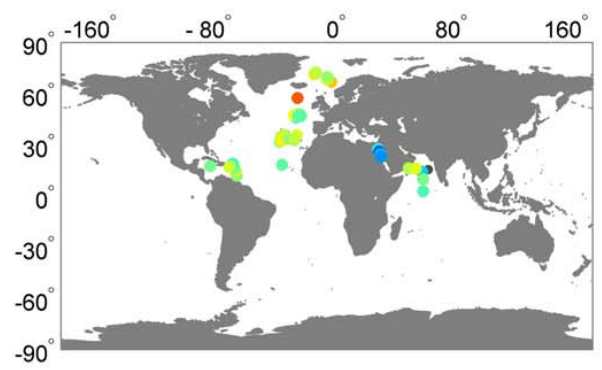

(b)

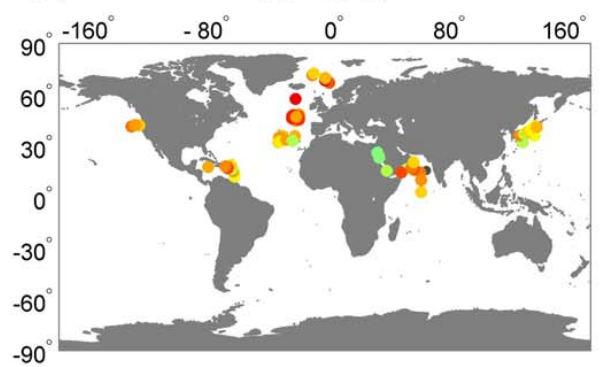

(d) $100-200 \mathrm{~m}$

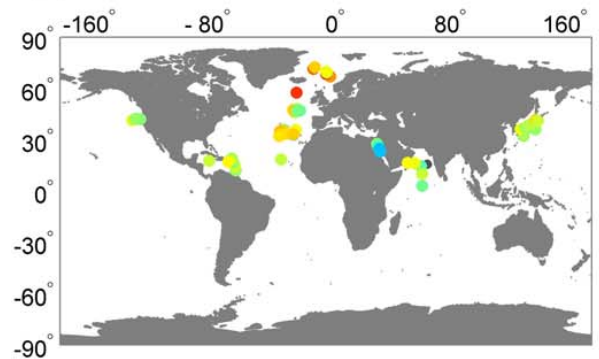

(f)

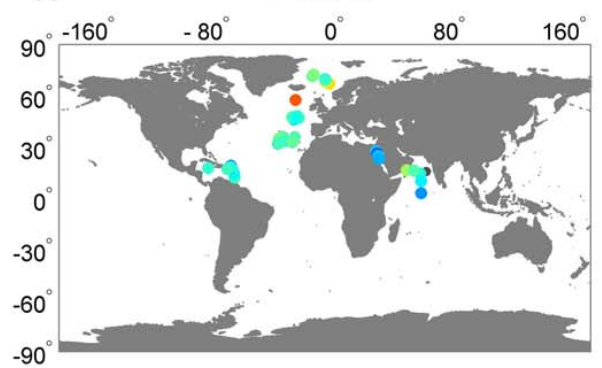

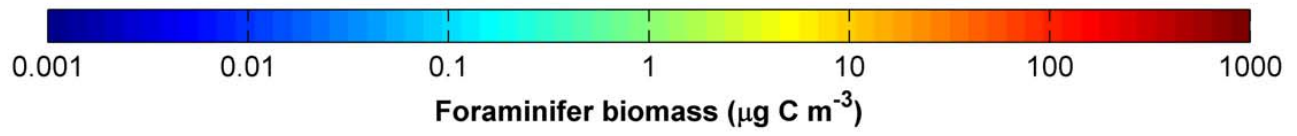

Figure 12. Log-normalised average depth related PFAB $\left(\log _{10} \mu \mathrm{g} \mathrm{C} \mathrm{m}^{-3}\right)$ binned on a $3 \times 3^{\circ}$ grid, comprising the North Atlantic Ocean, Caribbean, Arabian Sea and Gulf of Aden, and Red Sea.

individuals of $\sim 12-125 \mu \mathrm{m}$ in size (cf. Brummer and Kroon, 1988). Given that the number of individuals of a population decreases over time, and assuming that the average faunal contribution of individuals $>100-125 \mu \mathrm{m}$ in size amounts to $50 \%$ of the total fauna $>100 \mu \mathrm{m}$ (Table 3; Schiebel and Hemleben, 2000), the numbers given above $(>125 \mu \mathrm{m})$ would possibly be twice as high when including individuals $>100-125 \mu \mathrm{m}$, and more than three time as high for the entire planktic foraminifer fauna including juvenile and neanic individuals. A conservative first-order estimate of the entire global planktic foraminifer biomass production might hence range at $\sim 25-100 \mathrm{Tg} \mathrm{C} \mathrm{yr}^{-1}$, which is about half that of the estimated diazotroph biomass (Luo et al., 2012: 40-200 Tg C), and 3-5\% the biomass of diatoms (Leblanc et al., 2012: 500-3000 Tg C).

\subsection{Uncertainties of the PFAB estimates}

This paper presents a first estimate of regional PFAB extrapolated to the global scale, and future estimates based on larger data sets might considerably deviate from the one presented here. We will therefore regularly update our data to improve spatial coverage. Although including wide geographical and ecological ranges, our data set lacks data from the Southern Hemisphere, and in particular data from the Southern Ocean would considerably improve our PFAB estimate. In addition, we will try to include data on biomass and standing 
stocks of small (including juvenile and neanic) specimens, as well as on the biomass of the symbionts of the symbiontbearing planktic foraminifer species. So far, conversion of protein biomass to cytoplasm carbon has only been verified by comparison with literature data (Michaels et al., 1995), and would need to be confirmed by species- and size-specific data from different seasons and regions. Finally, intercomparison of planktic foraminifer biomass data from laboratories using different methods of biomass analyses would be needed to verify the data presented here to enlarge the so far rather limited data set. Considering all of the uncertainties, the numbers given above need to be used with care, but seem to be reasonable in comparison to the estimates of other groups of plankton, for example, diazotrophs and diatoms presented by Luo et al. (2012) and Leblanc et al. (2012).

\section{Conclusions}

The protein biomass analysed with the bicinchoninic acid (BCA) method using nano-spectrophotometry is assumed a reliable measure of the individual planktic foraminifer cytoplasm carbon content. From 754 cytoplasm carbon data of 21 planktic foraminifer species and morphotypes we have constructed a data set on the assemblage biomass carbon of the fauna $>125 \mu \mathrm{m}$ in test size for a total of $1128 \mathrm{sam}$ ples including 13 water-depth intervals between the ocean surface and $2500 \mathrm{~m}$ water depth. Samples from the North Atlantic, Caribbean, Red Sea, and Arabian Sea cover oligotrophic to eutrophic sites from equatorial to subpolar latitudes from different years and seasons. Assuming an ocean area of $322 \times 10^{6} \mathrm{~km}^{2}$, which supports planktic foraminifer production over nine month per year results in a global plank-

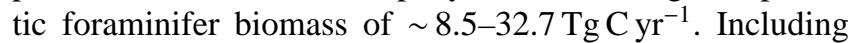
juvenile and neanic planktic foraminifers $<125 \mu \mathrm{m}$ in test size the total planktic foraminifer biomass production is assumed at $\sim 25-100 \mathrm{Tg} \mathrm{C} \mathrm{yr}^{-1}$.

Acknowledgements. We thank crew and shipboard scientific parties for their help in sampling. We are particularly grateful to the chief scientists Sascha Flögel (R/V Meteor 84/5) and Takashi Toyofuku (R/V Tansei-Maru KT11-20) for their support in sampling. Chris Beer helped with sampling and sample processing on $\mathrm{R} / \mathrm{V}$ Poseidon cruise 349. We are grateful to Fabien Lombard and Meike Vogt who inspired the paper as a contribution to the ESSDD special issue on plankton biomass. Meike and other contributors to the ESSDD issue did a great job in organizing a large group of contributors, communicating the methodology, and practical support. We thank Stéphane Pesant for integrating our data in the Pangaea data archive, Erik Buitenhuis for the gridding of our data, Collen O'Brien for creating the standard set of MAREDAT plots, and Frans Jorissen for his helpful comments on an earlier version of our manuscript. We are grateful to Fabien Lombard and Takashi Toyofuku for two detailed and constructive reviews, which helped to improve this paper. The work of AM was financially supported by the Regional Council of the Pays de La Loire, France.

Edited by: S. Pesant

\section{References}

Anderson, O. R., Spindler, M., Bé, A. W. H., and Hemleben, C.: Trophic activity of planktonic foraminifera, J. Mar. Biol. Assoc. UK, 59, 791-799, 1979.

Antoine, D., André, J.-M., and Morel, A.: Oceanic primary production, 2, Estimation at global scale from satellite (coastal zone color scanner) chlorophyll, Global Biogeochem. Cy., 10, 57-69, 1996.

Bé, A. H. W.: An ecological, zoogeographic and taxonomic review of Recent planktonic Foraminifera, in: Oceanic Micropaleontology, edited by: Ramsay, A. T. S., London, Academic Press, 1, $1-100,1977$.

Bé, A. W. H.: Biology of Planktonic Foraminifera, Foraminifera: Notes for a Short Course, in: Studies In Geology, edited by: Broadhead, T. W., Univ. Tennessee, 6, 51-92, 1982.

Beer, C. J., Schiebel, R., and Wilson, P. A.: Technical Note: On methodologies for determining the size-normalised weight of planktic foraminifera, Biogeosciences, 7, 2193-2198, doi:10.5194/bg-7-2193-2010, 2010.

Berger, W. H.: Global Maps of Ocean Productivity, in: Productivity of the Ocean: Present and Past, Dahlem Workshop Reports, edited by: Berger, W. H., Smetacek, V. S., and Wefer, G., Life Sci. R., John Wiley, New York, 44, 429-455, 1989.

Berger, W. H., Fischer, K., Lai, C., and Wu, G.: Ocean carbon flux: Global maps of primary production and export production, in: Biogeochemical Cycling and Fluxes Between the Deep Euphotic Zone and Other Oceanic Realms, edited by: Agegian, C., NOAA Natl. Undersea Res. Prog. Res. Rep., 88, 131-176, 1988.

Bijma, J. and Hemleben, Ch.: Population dynamics of the planktic foraminifer Globigerinoides sacculifer (Brady) from the central Red Sea, Deep-Sea Res. Pt. I, 41, 485-510, 1994.

Bijma, J., Faber, W. W., and Hemleben, C.: Temperature and salinity limits for growth and survival of some planktonic foraminifers in laboratory cultures, J. Foramin. Res., 20, 95-116, 1990.

Bollmann, J., Quinn, P. S., Vela, M., Brabec, B., Brechner, S., Cortés, M. Y., Hilbrecht, H., Schmidt, D. N., Schiebel, R., and Thierstein, H. R.: Automated particle analysis: Calcareous microfossils, in: Image Analysis, Sediments and Paleoenvironments, edited by: Francus, P., Kluwer Academic Publishers, Dordrecht, The Netherlands, 229-252, 2004.

Brummer, G. J. A. and Kroon, D.: Planktonic foraminifers as tracers of ocean-climate history, Ph.D. Thesis, Amsterdam, Free University Press, 346 pp., 1988.

Caron, D. A. and Bé, A. W. H.: Predicted and observed feeding rates of the spinose planktonic foraminifer Globigerinoides sacculifer, B. Mar. Sci., 35, 1-10, 1984.

Clayton, C. R. I., Abbireddy, C. O. R., and Schiebel, R.: A method of estimating the form of coarse particulates, Geotechnique, doi:10.1680/geot.2007.00195, 2009.

Dietrich, G., Kalle, K., Krauss, W., and Siedler, G.: Allgemeine Meereskunde, 3, Auflage, Gebrüder Bornträger, Berlin, Stuttgart, 593 pp., 1975.

Hemleben, C., Spindler, M., and Anderson, O. R.: Modern planktonic Foraminifera, New York, Springer, 363 pp., 1989.

Itou, M., Ono, T., Oba, T., and Noriki, S.: Isotopic composition and morphology of living Globorotalia scitula: a new proxy of subintermediate ocean carbonate chemistry, Mar. Micropaleontol., 42, 189-210, 2001. 
Kuroyanagi, A. and Kawahata, H.: Vertical distribution of living planktonic foraminifera in the seas around Japan, Mar. Micropaleontol., 53, 173-196, 2004.

Leblanc, K., Arístegui, J., Armand, L., Assmy, P., Beker, B., Bode, A., Breton, E., Cornet, V., Gibson, J., Gosselin, M.-P., Kopczynska, E., Marshall, H., Peloquin, J., Piontkovski, S., Poulton, A. J., Quéguiner, B., Schiebel, R., Shipe, R., Stefels, J., van Leeuwe, M. A., Varela, M., Widdicombe, C., and Yallop, M.: A global diatom database - abundance, biovolume and biomass in the world ocean, Earth Syst. Sci. Data Discuss., 5, 147-185, doi:10.5194/essdd-5-147-2012, 2012.

Lombard, F., Labeyrie, L., Michel, E., Bopp, L., Cortijo, E., Retailleau, S., Howa, H., and Jorissen, F.: Modelling planktic foraminifer growth and distribution using an ecophysiological multi-species approach, Biogeosciences, 8, 853-873, doi:10.5194/bg-8-853-2011, 2011

Loncaric, N., Peeters, F. J. C., Kroon, D., and Brummer, G. J. A.: Oxygen isotope ecology of recent planktic foraminifera at the central Walvis Ridge (SE Atlantic), Paleoceanography, 21, PA3009, doi:10.1029/2005PA001207, 2006.

Longhurst, A. R.: Ecological Geography of the Sea, 2nd Ed., Academic Press, 560 pp., 2007.

Luo, Y.-W., Doney, S. C., Anderson, L. A., Benavides, M., Bode, A., Bonnet, S., Boström, K. H., Böttjer, D., Capone, D. G., Carpenter, E. J., Chen, Y. L., Church, M. J., Dore, J. E., Falcón, L. I., Fernández, A., Foster, R. A., Furuya, K., Gómez, F., Gundersen, K., Hynes, A. M., Karl, D. M., Kitajima, S., Langlois, R. J., LaRoche, J., Letelier, R. M., Marañón, E., McGillicuddy Jr., D. J., Moisander, P. H., Moore, C. M., Mouriño-Carballido, B., Mulholland, M. R., Needoba, J. A., Orcutt, K. M., Poulton, A. J., Raimbault, P., Rees, A. P., Riemann, L., Shiozaki, T., Subramaniam, A., Tyrrell, T., Turk-Kubo, K. A., Varela, M., Villareal, T. A., Webb, E. A., White, A. E., Wu, J., and Zehr, J. P.: Database of diazotrophs in global ocean: abundances, biomass and nitrogen fixation rates, Earth Syst. Sci. Data Discuss., 5, 47106, doi:10.5194/essdd-5-47-2012, 2012.

Michaels, A. F., Caron, D. A., Swanberg, N. R., Howse, F. A., and Michaels, C. M.: Planktonic sarcodines (Acantharia, Radiolaria, Foraminifera) in surface waters near Bermuda: abundance, biomass and vertical flux, J. Plankton Res., 17, 131-163, 1995.

Milliman, J. D. and Droxler, A. W.: Neritic and pelagic carbonate sedimentation in the marine environment: Ignorance is not bliss, Geol. Rundsch., 85, 496-504, 1996.

Mojtahid, M., Zubkov, M., Hartmann, M., and Gooday, A.: Grazing of intertidal benthic foraminifera on bacteria: Assessment using pulse-chase radiotracing, J. Exp. Mar. Biol. Ecol., 399, 25-34, 2011.

Movellan, A.: Planktic foraminifer biomass and its effect on the biological carbon pump, Ph.D. thesis, University of Angers, in preparation, 2012.

Movellan, A., Schiebel, R., Zubkov, M. V., Smyth, A., and Howa, H.: Quantification of protein biomass of individual foraminifers using nano-spectrophotometry, Biogeosciences Discuss., 9, 6651-6681, doi:10.5194/bgd-9-6651-2012, 2012.

Obata, A., Ishizaka, J., and Endoh, M.: Global verification of critical depth theory for phytoplankton bloom with climatological in situ temperature and satellite ocean color data, J. Geophys. Res., 101, 20657-20667, 1996.
Ortiz, J. D., Mix, A. C., and Collier, R. W.: Environmental control of living symbiotic and asymbiotic Foraminifera of the California Current, Paleoceanography, 10, 987-1009, 1995.

Peeters, F. J. C. and Brummer, G.-J. A.: The seasonal and vertical distribution of living planktic foraminifera in the NW Arabian Sea, Geol. Soc. Spec. Publ., 195, 463-497, doi:10.1144/GSL.SP.2002.195.01.26, 2002.

Peeters, F., Ivanova, E., Conan, S., Brummer, G.-J., Ganssen, G., Troelstra, S., and van Hinte, J.: A size analysis of planktic foraminifera from the Arabian Sea, Mar. Micropaleontol., 36, 31-63, 1999.

Retailleau, S., Howa, H., Schiebel, R., Lombard, F., Eynaud, F., Schmidt, S., Jorissen, F., and Labeyrie, L.: Planktic foraminiferal production along an offshore-onshore transect in the southeastern Bay of Biscay, Cont. Shelf Res., 29, 1123-1135, doi:10.1016/j.csr.2008.12.021, 2009.

Retailleau, S., Schiebel, R., and Howa, H.: Population dynamics of living planktic foraminifers in the hemipelagic southeastern Bay of Biscay, Mar. Micropaleontol., 80, 89-100, 2011.

Schiebel, R.: Planktic foraminiferal sedimentation and the marine calcite budget, Global Biogeochem. Cy., 16, 1065, doi:10.1029/2001GB001459, 2002.

Schiebel, R. and Hemleben, C.: Interannual variability of planktic foraminiferal populations and test flux in the eastern North Atlantic Ocean (JGOFS), Deep-Sea Res. Pt. II, 47, 1809-1852, 2000.

Schiebel, R. and Hemleben, Ch.: Modern Planktic Foraminifera, Palaeont. Z., 79, 135-148, 2005.

Schiebel, R., Hiller, B., and Hemleben, C.: Impacts of storms on recent planktic foraminiferal test production and $\mathrm{CaCO}_{3}$ flux in the North Atlantic at $47^{\circ} \mathrm{N}, 20^{\circ} \mathrm{W}$ (JGOFS), Mar. Micropaleontol., 26, 115-129, 1995.

Schiebel, R., Waniek, J., Bork, M., and Hemleben, C.: Planktic foraminiferal production stimulated by chlorophyll redistribution and entrainment of nutrients, Deep-Sea Res. Pt. I, 48, 721-740, 2001.

Schmuker, B. and Schiebel, R.: Spatial and temporal distribution of planktic foraminifers in the eastern Caribbean, Mar. Micropaleontol., 46, 387-403, 2002.

Siccha, M., Schiebel, R., Howa, H., and Schmidt, S.: Short-term and small scale variability in planktic foraminifera test flux rates in the Bay of Biscay, Deep-Sea Res. Pt. I, 64, 146-156, 2012.

Smith, P., Krohn, R., Hermanson, G., Mallia, A., Provenzano, M., Fujimoto, E., Goeke, N., Olson, B. J., and Klenk, D.: Measurement of protein using bicinchoninic acid, Anal. Biochem., 150, 76-85, 1985.

Spindler, M. and Dieckmann, G. S.: Distribution and abundance of the planktic foraminifer Neogloboquadrina pachyderma in sea ice of the Weddell Sea (Antarctica), Polar Biol., 5, 185-191, 1986.

Spindler, M., Hemleben, C., Salomons, J. B., and Smit, L. P.: Feeding-behavior of some planktonic foraminifers in laboratory cultures, J. Foramin. Res., 14, 1-3, 1984.

Vincent, E. and Berger, W. H.: Planktonic Foraminifera and their use in paleoceanography. The Oceanic Lithosphere, in: The Sea, edited by: Emiliani, C., 7, 1025-1119, 1981.

Volkmann, R.: Planktic foraminifers in the outer Laptev Sea and Fram Strait - modern distribution and ecology, J. Foramin. Res., 30, 157-176, 2000. 
Weyl, P. K.: Micropalenotology and the ocean surface climate, Science, 202, 475-481, 1978.

Yoder, J. A., McClain, C. R., Feldman, G. C., and Esaias, W. E.: Annual cycles of phytoplankton chlorophyll concentrations in the global ocean: a satellite view, Global Biogeochem. Cy., 7, 181193, 1993.

Zubkov, M. V. and Sleigh, M. A.: Growth of Amoebae and Flagellates on Bacteria Deposited on Filters, Microb. Ecol., 37, 107$115,1999$.
Zubkov, M. V., Fuchs, B. M., Eilers, H., Burkill, P. H., and Amann, R.: Determination of Total Protein Content of Bacterial Cells by SYPRO Staining and Flow Cytometry, Appl. Environ. Microb., 65, 3251-3257, 1999. 